\title{
A Conceptual Framework of Design and Material Process of Bagasse for Furniture Application
}

\author{
Shahril Safian 1, Mohammad Azroll Ahmad 1, Shahril Anuar Bahari 2, Oskar Hasdinor Hassan ${ }^{1}$ \\ ${ }^{1}$ Faculty of Art \& Design, ${ }^{2}$ Faculty of Applied Science, \\ Universiti Teknologi MARA, Shah Alam Selangor, Malaysia
}

shahrilsafianuitm@gmail.com, mazroll870@uitm.edu.my, sbinbahari@gmail.com,oskarhasdinor@gmail.com Tel: 018-966-7336

\begin{abstract}
This conceptual framework uses bagasse as potential material for furniture design application. Bagasse has been used as an industrial material manufacturing process, some information detected in furniture manufacturing literature. Aims, to identify bagasse in the form of biocomposite material that able used in furniture application. This research was undertaken, where research methods were developed and the material was tested, documented and analysed to inform this biocomposite in furniture design development process. The objective provided new knowledge on bagasse as potential material for furniture design application. This paper acts as material processing outlines and provides preliminary evaluation for final phase results.
\end{abstract}

Keywords: Conceptual framework; material process; bagasse; furniture design

eISSN: 2398-4287 @ 2020. The Authors. Published for AMER ABRA cE-Bs by e-International Publishing House, Ltd., UK. This is an open access article under the CC BYNC-ND license (http://creativecommons. org/licenses/by-nc-nd/4.0). Peer-review under responsibility of AMER (Association of Malaysian Environment-Behaviour Researchers), ABRA (Association of Behavioural Researchers on Asians) and cE-Bs (Centre for Environment-Behaviour Studies), Faculty of Architecture, Planning \& Surveying, Universiti Teknologi MARA, Malaysia. DOI: https://doi.org/10.21834/ebpj.v5iSI1.2304

\subsection{Introduction}

Malaysian hawkers use yellow sugarcane Saccharum officinarum for producing daily drinking juice. However, sugarcane wastes (bagasse and pith) have become problematic in their disposal especially at night market and retail shop (Leang \& Saw, 2011). In manufacturing sustainable design of bagasse composite, a suitable mass production framework has opted through Life Cycle Assessment (LCA) (Kurilova-Palisaitiene et al., 2015). This natural waste material is able to be used in sustainable design as it gives an innovated product through bio-composite that could become potential in furniture mass production. To sum up, as sustainable designers need to come out with design solution before implementing the LCA and Design and Build (D\&B), they are required to understand the basic existing manufacturing technology and technique (Chen et al., 2015).

Next, Design for Sustainable (DfS) is used to engage in design evaluation for industrial design to develop design via the material process (Vallet et al., 2014). In addition, Design for Environment (DfE) helps to analyse the manufacturing process using the LCA framework in designing furniture component that would be able to deliver into a mass production line. This provides benefit to increase the economy of the sustainable production line (Prendeville et al., 2012).

Using the End of Life (EoF) concept, the material manufacturing process can enhance the economy by generating more profit for the furniture industry by improving the existing technology (Sproedt et al., 2015). In this manuscript, the authors propose a conceptual framework design for the furniture industry, as to engage with the material manufacturing process. Moreover, this conceptual framework can be the guideline for both industry players and designers through the development of the design process. This will help them in applying the understanding of material properties and design aspects for furniture application. 


\subsection{Literature Review}

\subsubsection{A Major Sustainable Manufacturing Process}

Some of the potential green sustainable materials that have been used in mass industry are rice husk, coconut husk, banana, palm oil, pineapple and bamboo (Chen et al., 2017). These natural plants are in good uses through mass furniture industry especially in wood composite and laminated wood composite production. In this line, a conceptual framework of LCA has helped designer and practitioner to study the flow of production of furniture seating component through mass production line (Seow et al., 2016). However, it is essential for a sustainable designer, material scientist and manufacturer to team up and work together in a sustainable mass production using D\&B development technology in order to assist the LCA framework in the manufacturing process (De Giacomo et al., 2014).

A sustainable design process of particleboard in Malaysia increased by $1.6 \%$ since January 2017, and according to Yatie (2017), this could give a positive impact for a local manufacturer to gain new design experience through the development process of material processing. Several examples of bagasse-composite product applications in the sustainable manufacturing process were conducted by Dungani et al. (2016), where a manufactured automotive component, food packaging, building component, a medical application using bagasse-composite. The authors believe that the bagasse-composite materials have good potential uses via mass manufacturing, for example, furniture seating component.

\subsubsection{Roles of Sustainable Designer}

The sustainable green mass production framework Fig. 1 is based on the reviewed journals for industrial design and bio-composite mass production line. Through this review, the LCA framework for furniture sustainable mass production design is very important for designers to study the development of a mass manufacturing process (May et al., 2016). This paper includes several previous studies of the conceptual framework that will help the sustainable designers and manufacturers to understand the conceptual flow of the sustainable design process for furniture products, e.g. seat component.

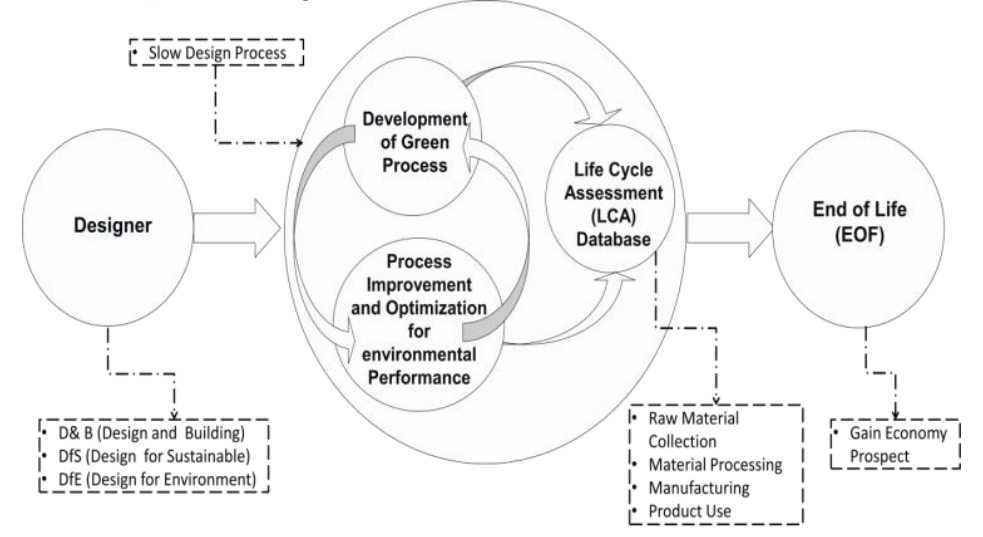

Fig. 1: Sustainable green design mass production conceptual framework and manufacturing process

\subsubsection{Design and Build (D\&B)}

D\&B framework through designing natural mass production is an example of bagasse-composite for seating component from $S$. officinarum. It is the first guideline for a designer to use the LCA framework (Michalik et al., 2014). This framework gives benefit for sustainable furniture designers to learn mass production via a lean manufacturing process. In addition, they agreed that this framework can increase demands through material manufacturing process, in which, it is able to maximize potential green furniture development technology, such as Hot air Moulding Template (HAMP), as it could cut down energy consumption by 25\% (Hu et al., 2017; Leite \& Vieira, 2015).

Sustainable material designers that opted D\&B framework via LCA framework for mass manufacturing, such as bagasse-composite for furniture seating component, can compile several experiment results (Li et al., 2017). According to Boetker et al. (2016), they included three domains of green mass which were simple geometry form design, manufacturing processing tools and performance of a product, in which every manufacturing designer need to possess.

\subsubsection{Design for Sustainable (DfS)}

The DfS frameworks are usable for designers dealing with natural waste material. Roger (2010), expanded the three ideations from D\&B framework development movement. Those are Eco-Centric, Techno-Centric and Socio-Centric. These three levels of design thinking reviewed by Humphries-Smith, (2008), had potential use in the development of material and manufacturing process for furniture sustainable design. Furthermore, it is one part of ideation in designing a flow chart process that is able to combine as a developed manufacturing process. Based on the DfS framework via furniture production line, it is important for designers to recognize the potential use of natural bio-composite material according to previous designs, hence, the sustainable designers must be able to formularize the end result of furniture component that suits for consumers (Ko et al., 2015).

\subsubsection{Design for Environment (DfE)}

Designers using DfE are able to optimize the performance of the manufacturing design process and it gives benefit through productivity 
value to sustain natural waste material for the future market (Rosen \& Kishawy, 2012). This idea agreed by Haemmerle et al. (2012), as this framework gives the potential for sustainable designers to be involved with the design process, such as in bagasse-composite for seating component. However, some examples of the DfS design process are required to be made into conceptual design sketches like natural waste bio-composite tables. This will help designers to understand their potential furniture design (Barata et al., 2016). The DfE requirement is used as a tool to evaluate designer sketches, mock-up, or 3D modelling tools to analyze the potential of DfS, D\&B and ultimately able to enhance the User Interface (UI) via LCA (Mattioda et al., 2014).

\subsubsection{Life Cycle Assessment (LCA)}

The LCA used for furniture mass production includes three combinations (D\&B, DfS and DfE) which help Cradle to Cradle become more establish with sustainable composite material from S. officinarum (Stefano \& Vergara, 2013). The LCA framework gives a potential towards gaining good economy impact via sociology in the waste manufacturing process through the Slow Design Process. The LCA framework is part of adaptation process via previous D\&B design framework, thus, it helps designers to develop the new process in order to improve furniture mass design process using $S$. officinarum to enhance the economic aspect in DfS (Finkbeiner et al., 2010).

The LCA framework is allowed to be evaluated via experimental slow design flow chart and it gives chance for composite material from S. officinarum in manufacturing seating component and maximizes the potential of sustainability (Dovramadjiev et al., 2013; Liu et al., 2015). Lastly, those strategies via LCA framework of D\&B, DfS, and DfE for furniture mass production have reflected back to Cradle to Cradle in improving sustainable design process flow chart using bagasse-composite seating furniture component. This gives the designer to perform LCA framework experiment for clean production (Almeida et al., 2015).

\subsubsection{End of Life (EoF)}

A conceptual EoF framework has been used as innovation towards technological development to improve sustainable manufacturing natural material process through LCA, DfE, and DfS towards Cradle to Cradle, in the case of furniture seating component from bagassecomposite (Dangelico \& Pujari, 2010). Sustainable manufacturing from disposal raw material like bagasse, for mass manufacturing furniture seating component, is a best practice for designers, thus, it can improve economy and profit through customers demand (Lewandowski, 2016). Finally, this conceptual framework through mass manufacturing of bagasse-composite has the potential to be manufactured via Cradle to Cradle and the technology development such as HAMP using D\&B, DfS, DfE and LCA.

\subsection{The Framework of the Study}

This study will mix the methodologies through conducting several experiments based on literature reviews and several collections of bagasse at night market used for furniture manufacturing Fig. 2 .

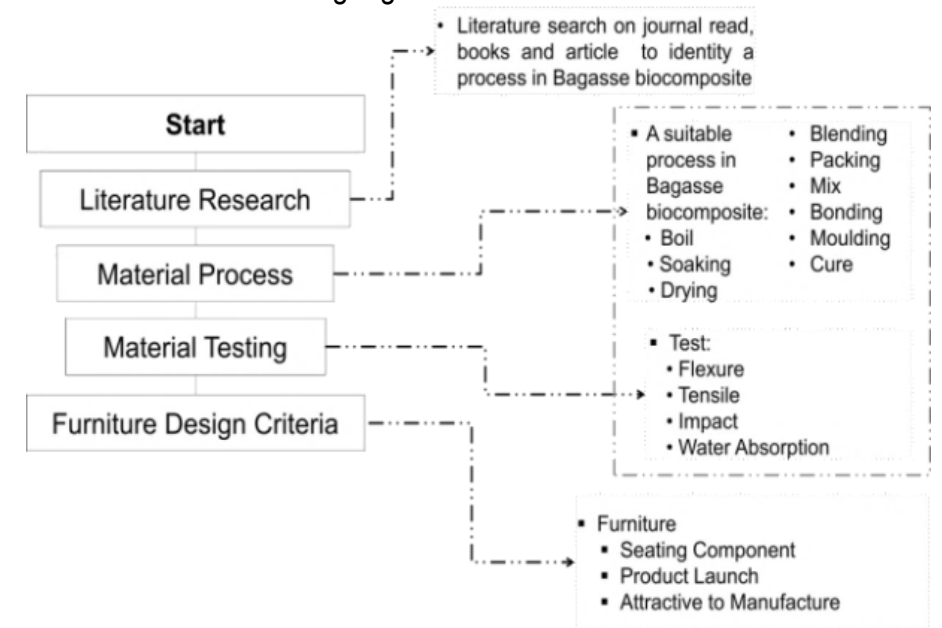

Fig. 2: Conceptual Framework

The methodologies are to analyze the method of mixing and bonding of the composites product. The task's classification is through manufacturing to design development. The research will start by collecting several journals, articles, and books, regarding the projects, which related to laboratory processing. After the literature reviews, the next step is the material processing, such as bagasse boiling, soaking, drying, blending, packing, mix, bonding, moulding, and finally curing. Then, the composites will go into material testing stages such as flexural, tensile, impact and water absorption tests. These properties are very crucial for the development of product design.

Finally, the outcomes will be based on a few furniture component samples and outcome from the material testing. The component design criteria (as a final product) will implement all material technologies, especially in the production of furniture seating component. Moreover, the product will contribute to the technology and manufacturing process development for a furniture manufacturer in gaining attractive markets and profits. 


\subsection{Results and Discussion Developing Bagasse Composite}

In this study, bio-composite material was developed from the collected bagasse. The development of this bio-composite based on material process guideline, which it is able to demonstrate a typical manufacturing process for bio-composite. All activities can be divided into three main segments. Firstly, material preparation; where raw sugarcane disposals were collected around the night market in Klang Valley and stored properly in plastic containers. Secondly, material treatment; the collected bagasse were treated through the boiling process for four (4) hours using induction stove with $220^{\circ} \mathrm{C}$ temperature, and later, the raw bagasse left for a cooling process under room temperature. Finally, the drying process; the drying process involves three different stages; eight hours of sun-dried, three days of air-dried, twenty-two days of oven-dried under $100^{\circ} \mathrm{C}$ temperature. At this stage, the processed raw sugarcane bagasse was considered as cured and proceeded to the next process, called the experimental phase.

The experimental phase was mainly related to treated material, sample preparation and testing. In preparing the samples for testing, the cured bagasse needs to get through these processes; material-mixing process, the cured material crushed into small particle using a blender and later categorized the particle sizes through filtering process using a screener. Screened bagasse material was preserved in a container for moisture protection. Later, in preparing the samples for testing, the cured and preserved particle of bagasse was mixed together with glue or bonding element. This was one of the important processes because the mixed bagasse particle and glue need to be homogeneously blended. In making this process successful, the authors used a planetary mixer machine to make sure the mixture became dough. The bagasse dough was laid-up and trimmed manually into prepared template mould. This process called HAMP preparation. The prepared bagasse dough was then placed and heated using a ceramic kiln chamber with specific temperature and time. After the samples of bagasse fully heated, the mould and sample were cooled down and conditioned under room temperature. The samples in a form of the bio-composite block were considered ready for flexure, tensile, water absorption and impact tests.

As outlined above, the preliminary results from the flexure strength of bagasse bio-composite were $33.70 \mathrm{~N}$ and the water absorption test was $148.43 \%$. The preliminary experimental results outlined above indicated that the bagasse bio-composite material has the potential for further development to improve the strength.

\subsection{Conclusion}

The use of bagasse will benefit the furniture industry through proper understanding of its material properties and design aspects. This conceptual framework paper will act as a general guideline for furniture manufacturers in producing agricultural waste-based composites product. To address this material manufacturing and design process conceptual framework via D\&B, DfS, DfE, LCA and EoF, designers are able to use disposal $S$. officinarum as the main material component in the manufacturing process. Meanwhile, the sustainable designer had to revise another potential of natural material as to add up in mass production that suit for the sustainable manufacturing process. Furthermore, the important part is there are no productions throughout the development of sustainable design in Malaysia that are using S. officinarum. Meanwhile, designers able to expand the study via the development of existing technology or technique as a tool to fulfil the requirement for furniture manufacturing, e.g. HAMP. As the end of this brief, the researcher hopes this project will be able for further development with the different approaches of technology throughout the sustainable manufacturing process for furniture design using S. officinarum.

\section{Acknowledgments}

The study was sponsored by Geran Inisiatif Penyeliaan (GIP) 600-IRMI/MyRA 5/3/GIP (079/2017) from Institute of Research Management \& Innovation (IRMI), UiTM. The authors would also like to extend their gratitude to the Faculty of Art \& Design and Faculty of Applied Sciences for providing the facility in this study.

\section{References}

Almeida, C. M. V. B., Agostinho, F., Giannetti, B. F., \& Huisingh, D. (2015). Integrating cleaner production into sustainability strategies: An introduction to this special volume. Journal of Cleaner Production, 96, 1-9.

Barata, T. Q. F., Rodrigues, O. V., Matos, B. M., \& Pinto, R. S. (2016). Furniture Design Using Mdf Boards Applying Concepts Of Sustainability. Product Management \& Development, 14(1), 68-83.

Boetker, J., Raijada, D., Aho, J., Khorasani, M., S??gaard, S. V., Arnfast, L., ... Rantanen, J. (2016). In silico product design of pharmaceuticals. Asian Journal of Pharmaceutical Sciences, 11(4), 492-499. https://doi.org/10.1016/j.ajps.2016.02.010

Chen, D., Heyer, S., Ibbotson, S., Salonitis, K., Steingrimsson, J. G., \& Thiede, S. (2015). Direct digital manufacturing: definition, evolution, and sustainability implications. Journal of Cleaner Production, 107, 615-625.

Chen, Y., Zhang, Q., Hu, W., Zhang, X., Wang, L., Hua, X., ... Zhang, J. (2017). Evolution and expression of the fructokinase gene family in Saccharum. BMC Genomics, 18(1), 197.

Dangelico, R. M., \& Pujari, D. (2010). Mainstreaming green product innovation: Why and how companies integrate environmental sustainability. Journal of Business Ethics, 95(3), 471-486. 
De Giacomo, M., Loprieno, A., Tarantini, M., Preka, R., Litido, M., Furphy, A., ... Gabarrell, X. (2014). Eco-Innovative Practices for Sustainable Consumption and Production: What are the Possible Benefits for Companies? Administrative Sciences, 4(3), 242-275.

Dovramadjiev, T., Bratanov, P. P., Cankova, K., \& Jecheva, G. (2013). Design of Multifunctional Ergonomic Furniture Made in Computer Environment Trough Leading 3D Software Products. Machines, Technologies, Materials Journal, (11), 44-45.

Dungani, R., Karina, M., Subyakto, Sulaeman, A., Hermawan, D., \& Hadiyane, A. (2016). Agricultural waste fibers towards sustainability and advanced utilization: A review. Asian Journal of Plant Sciences.

Finkbeiner, M., Schau, E. M., Lehmann, A., \& Traverso, M. (2010). Towards life cycle sustainability assessment. Sustainability, 2(10), 3309-3322.

Haemmerle, L., Shekar, A., \& Walker, D. (2012). Key concepts of radical innovation for sustainability, with complementary roles for industrial design and engineering. International Journal of Sustainable Design, 2(1), 24

Hu, L., Peng, C., Evans, S., Peng, T., Liu, Y., Tang, R., \& Tiwari, A. (2017). Minimising the machining energy consumption of a machine tool by sequencing the features of a part. Energy, 121, 292-305.

Humphries-Smith, T. (2008). Sustainable design and the design curriculum. J of Design Research, 7, 259-274.

Ko, K., Ramirez, M., \& Ward, S. (2015). A framework for understanding the role of product attachment in enabling sustainable consumption of household furniture. Product Lifetimes And The Environment, (June), 8-10.

Kurilova-Palisaitiene, J., Lindkvist, L., \& Sundin, E. (2015). Towards Facilitating Circular Product Life-Cycle Information Flow via Remanufacturing. Procedia CIRP, 29, 780-785.

Leang, Y. H., \& Saw, H. Y. (2011). Proximate and functional properties of sugarcane bagasse. Agro Food Industry Hi-Tech, 22(2), 5-8.

Leite, H. dos R., \& Vieira, G. E. (2015). Lean philosophy and its applications in the service industry: a review of the current knowledge. Production, $25(3), 529-541$.

Lewandowski, M. (2016). Designing the business models for circular economy-towards the conceptual framework. Sustainability (Switzerland), 8(1), 1-28.

Li, S., Kattner, U. R., \& Campbell, C. E. (2017). A Computational Framework for Material Design. Integrating Materials and Manufacturing Innovation, 6(7), 1-20.

Liu, T., Hertzmann, A., Li, W., \& Funkhouser, T. (2015). Style compatibility for 3D furniture models. ACM Transactions on Graphics, 34(4), 85:1-85:9.

Mattioda, R. A., Canciglieri, O., Fernandes, P. T., Casela, J. L., \& Mazzi, A. (2014). Thoughts on Product Development Oriented to Sustainability in Organizational Overview. Advanced Materials Research, 1061-1062(January), 1238-1244.

May, G., Stahl, B., Taisch, M., \& Kiritsis, D. (2016). Energy management in manufacturing: From literature review to a conceptual framework. Journal of Cleaner Production, (July 2017), 1-26.

Michalik, J., Joyce, J., Barney, R., \& McCune, G. (2014). 3D opportunity for product design : Additive manufacturing and at the early stage. (J. J. Joann Michalik, Ed.) Deloitte University press (2015th ed.). Deloitte: Deloitte Touche Tohmatsu Limited.

Prendeville, S., Connor, F. O., Rafferty, S. O., \& Palmer, L. (2012). Material selection and design for sustainable material innovation. Proceedings of the European Academy of Design Conference - Crafting the Future, 1-12.

Roger, S. S. (2010). An Introduction to Sustainable Development in The Engineering Curriculum. (H. E. A. E. S. Centre, Ed.) (1st Editio). Newcastle City Campus, 2 Ellison PI, Newcastle upon Tyne NE1 8ST, UK: The Higher Education Academy Engineering Subject Centre.

Retrieved from http://nrl.northumbria.ac.uk/id/eprint/784

Rosen, M. A., \& Kishawy, H. A. (2012). Sustainable manufacturing and design: Concepts, practices and needs. Sustainability.

Seow, Y., Goffin, N., Rahimifard, S., \& Woolley, E. (2016). A "Design for Energy Minimization" approach to reduce energy consumption during the manufacturing phase Energy, 109, 894-905

Sproedt, A., Plehn, J., Schönsleben, P., \& Herrmann, C. (2015). A simulation-based decision support for eco-efficiency improvements in production systems. Journal of Cleaner Production, 105, 389-405.

Stefano, N. M., \& Vergara, L. G. L. (2013). Bibliometrics techniques and content analysis review applied to ecodesign: Initial proposal for future studies. Espacios 34(6), 8. Retrieved from http://www.revistaespacios.com/a13v34n06/13340608.html

Vallet, F., Eynard, B., \& Millet, D. (2014). Proposal of an eco-design framework based on a design education perspective. Procedia CIRP, 15, 349-354.

Yatie, H. (2017). Malaysin Timber E-Stats 2017. Menara PGRM, 8, Jalan Pudu Hulu, Taman Pertama, 55300 Kuala Lumpur, Wilayah Persekutuan Kuala Lumpur, Malaysia. Retrieved from http://www.mtib.gov.my/index.php?option=com exile stats\&view=stats\&format=raw\&id=2057 